\title{
Cultural Trauma and the Song of Moses (Deut 32)
}

\author{
Dominik Markl (Pontifical Biblical Institute AND \\ University of Pretoria)
}

\begin{abstract}
The Song of Moses blames Israel for the idolatry that caused divine wrath and led to the people's near annihilation by their enemies. This article analyses the Song's structure and dynamics, its rhetoric of blaming and shaming, and its literary context within the book of Deuteronomy before re-evaluating the Song's message through the lens of psychological and sociological trauma theory. Psychological research on the relation between trauma and feelings of guilt and shame helps us to understand the divine message of blaming and shaming as an externalised transformation of self-blame. Through the lens of the sociological concept of cultural trauma, the Song can be seen as an intellectual 'working through' of past collective suffering that marks the community's identity for the future.
\end{abstract}

KEYWORDS: Song of Moses (Deuteronomy 32), Book of Deuteronomy, Trauma studies, Cultural trauma, Collective identity

\section{A HISTORY OF RESEARCH AND TRAUMA THEORY}

The Song of Moses in Deut 32:1-43 is the most extensive poem in the Pentateuch, and its position towards the end lends it structural weight. The Song's exceptional form and language have attracted intense exegetical interest. The notorious complexity of the Song's textual transmission ${ }^{1}$ involves significant variants, especially in vv. 8 and 43, with implications for Israel's history of religion. ${ }^{2}$ The sheer diversity of proposals for the Song's date render

* Submitted: 05/10/2020; peer-reviewed: 13/10/2020; accepted: 01/12/2020. Dominik Markl, "Cultural Trauma and the Song of Moses (Deut 32)," Old Testament Essays 33 no. 3 (2020): 674-689. DOI: https://doi.org/10.17159/23123621/2020/v33n3a18.

1 The most recent analysis is Petra Schmidtkunz, Das Moselied des Deuteronomiums: Untersuchungen zu Text und Theologie von Dtn 32,1-43 (FAT 2. Reihe 124; Tübingen: Mohr Siebeck, 2020), 17-47. An extensive and careful dissertation on the Song's text unfortunately remained unpublished: Bruno Volkwein, Textkritische Untersuchungen zu Dtn 32,1-43 (Ph.D. diss.; Pontifical Biblical Institute, Rome, 1973).

2 See the discussion in connection with Deuteronomy 4 in Adrian Schenker, "Das Paradox des israelitischen Monotheismus in Dtn 4,15-20: Israels Gott stiftet Religion 
it a paradigmatic case for the challenges of historical research in the Hebrew Bible. ${ }^{3}$ Many authors have argued for an early date based on linguistic observations, and Paul Sanders, in his extensive monograph, concludes that "a pre-exilic date is almost certain for the song as a whole." However, Eckart Otto more recently argued for a late post-exilic date, as he considers the Song to be a mosaic of allusions to the prophets, psalms and wisdom writings. ${ }^{5}$ The three most recent dissertations on Deut 32 date the text to the post-exilic period, ${ }^{6}$ concentrating on the theological issue of divine violence, ${ }^{7}$ the history of the Song's motifs, ${ }^{8}$ questions of social memory and identity, and the Song's relationship with Deutero-Isaiah. ${ }^{9}$

The narrative context of Deut 31:16-32:43 portrays the Song as divine revelation mediated through Moses $^{10}$ to announce Israel's future suffering because of the people's own sin. The authors of these texts, in contrast, were

und Kultbilder der Völker," in Bilder als Quellen. Images as Sources: Studies on Ancient Near Eastern Artefacts and the Bible Inspired by the Work of Othmar Keel (OBO Sonderband; Fribourg: Academic Press/Göttingen: Vandenhoeck \& Ruprecht, 2007), 511-528; Georg Braulik, "Hat Gott die Religionen der Völker gestiftet? Deuteronomium 4,19 im Kontext von Kultbilderverbot und Monotheismus," in Tora und Fest: Aufsätze zum Deuteronomium und zur Liturgie (ed. idem; SBAB 69; Stuttgart: Katholisches Bibelwerk, 2019), 184-188.

3 On the history of research, see Eckart Otto, Deuteronomium 23,16-34,12 (HThKAT; Freiburg: Herder, 2017), 2157-2163; idem, "Moses Abschiedslied in Deuteronomium 32," in idem, Die Tora. Studien zum Pentateuch: Gesammelte Aufsätze (BZAR 9; Wiesbaden: Harrassowitz, 2009), 641-650.

4 Paul Sanders, The Provenance of Deuteronomy 32 (OTS 37; Leiden: Brill, 1996), 431. This monograph provides an extensive overview of previous research.

5 See Otto, Deuteronomium, 2164-2171; idem, "Moses Abschiedslied."

6 Schmidtkunz, Das Moselied, 275, 377 (ca. 5th century); Christiane Wüste, FelsGeier-Eltern: Untersuchungen zum Gottesbild des Moseliedes (Dtn 32) (BBB 182, Göttingen: V\&R Unipress, 2018), 101 (pre-exilic kernel in vv.8-25, expanded in vv. 26-35, with postexilic additions in vv. 1-7 and 36-43). Tina Dykesteen Nilsen, The Origins of Deuteronomy 32: Intertextuality, Memory, Identity (New York: Peter Lang, 2018), 266, claims that, "Give Ear and Isa 1; 34-35; 56-66 were composed simultaneously in the same milieu, that is, Jerusalem in the first half of the Persian period (530-450 BCE)."

7 Wüste, Fels.

8 Schmidtkunz, Das Moselied.

9 Nilsen, The Origins.

10 On the complex interplay between the prophetic and the divine voices in the Song, see Jean-Pierre Sonnet, "Voix divines dans le cantique de Moïse (Deutéronome 32)," in La contribution du discours à la caractérisation des personnages bibliques: Neuvième colloque international du RRENAB, Louvain-la-Neuve, 31 mai-2 juin 2018 (ed. André Wénin; BEThL 311; Leuven: Peeters, 2020), 153-173. 
dealing with the historical experience of their people's suffering. The Song presupposes defeat by a foreign army that involved much bloodshed (32:25). Likely historical candidates ${ }^{11}$ for interpreters who prefer a pre-exilic date are the Assyrian conquests. ${ }^{12}$ Authors who opt for an exilic or post-exilic date tend to consider the Babylonian defeat of Judah as a specific point of reference..$^{13}$ The text may also telescope several instances of defeat in the past into a paradigmatic scenario. A basic question, however, remains. Why does the Song reflect on the history of military defeat in terms of a divine accusation against Israel, conveying the image of an extremely violent $\operatorname{God}^{14}$ who first wages war against Israel (vv. 20-25) and then against their enemies (vv. 41-42), who is full of contempt for his own people and boasts in self-glorification? Here, I propose to look at this question through the lens of trauma theory.

Psychological and sociological trauma studies and their reception in the study of literature have received increasing attention in biblical studies in the past decade. ${ }^{15}$ Psychological trauma theory helps to reflect on literature as a product of psychological processes that include, but are not limited to, intellectual reflection. While we do not have access to the psyche of any person who authored or redacted texts in antiquity, we cannot ignore the fact that such people were conditioned by basic psychic experiences, significantly including (traumatic) suffering and its (transgenerational) consequences. Contemporary psychologists describe self-blame as a frequent reaction to diverse forms of

11 On the history of research on the historical setting, see Sanders, Provenance, 6-40.

12 E.g., Sanders, Provenance, 433-435. Solomon A. Nigosian, "Historical Allusions for Dating Deut 32," BN 119/120 (2003): 30-34, argues for a 9th century BCE date and sees "Hazael's bloody campaigns" in the background of the Song (ibid., 34).

13 Thus, e.g., Nilsen, The Origins, 231.

14 See Wüste, Fels, 12-14.

15 See David M. Carr, Holy Resilience: The Bible's Traumatic Origins (New Haven: Yale University Press, 2014); Eve-Marie Becker et al., eds., Trauma and Traumatization in Individual and Collective Dimensions: Insights from Biblical Studies and Beyond (SANt 2; Göttingen: Vandenhoeck \& Ruprecht, 2014); David G. Garber, "Trauma Theory and Biblical Studies," CurBR 14 (2015): 24-44; Elizabeth Boase and Christopher G. Frechette, eds., Bible through the Lens of Trauma (Semeia Studies 86; Atlanta, GA: Society of Biblical Literature, 2016); Dominik Markl, "The Babylonian Exile as the Birth Trauma of Monotheism," Biblica 101 (2020): 1-25; idem, "Trauma/Traumatheorie," in WiBiLex (online). One of the few applications of trauma theory to Deuteronomy is William Morrow, "Deuteronomy 7 in Postcolonial Perspective: Cultural Fragmentation and Renewal," in Interpreting Exile: Displacement and Deportation in Biblical and Modern Contexts (ed. Brad E. Kelle, Frank Ritchel Ames and Jacob L. Wright; SBL Ancient Israel and Its Literature 10; Atlanta: Society of Biblical Literature, 2011), 275-293. 
trauma. ${ }^{16}$ Both guilt and shame are typical emotions related to post-traumatic stress disorder. ${ }^{17}$ Sociological trauma theory considers the wider social ramifications of traumatic events that affect large groups and are constructed as basic constituents of collective identity in discourse. According to Jeffrey Alexander's definition, "cultural trauma occurs when members of a collectivity feel they have been subjected to a horrendous event that leaves indelible marks upon their group consciousness, marking their memories forever and changing their future identity in fundamental and irrevocable ways." ${ }^{18}$ Since the Song of Moses makes strong claims about both the collective identity and the experience of defeat and suffering in Israel, trauma theory is a promising lens to re-evaluate its background and meaning.

In the following, I shall lay some interpretative groundwork by analysing the Song's structure and pragmatics before looking at its rhetoric of blaming and shaming as well as specific aspects of its contextualisation within Deuteronomy. Against this backdrop, I shall re-evaluate the Song as a literary transformation of cultural trauma.

\section{B THE SONG'S STRUCTURE AND DYNAMICS}

The structure of the Song of Moses has been much disputed, ${ }^{19}$ but some of its features are apparent. The first three verses are a proem in which the poetic voice speaks in first person singular and characterises the poem that follows (see

16 See, e.g., Mike Startup, Lebogang Makgekgenene and Rosemary Webster, "The Role of Self-blame for Trauma as Assessed by the Posttraumatic Cognitions Inventory (PTCI): A Self-protective Cognition?" Behaviour Research and Therapy 45 (2007): 395-403.

17 Lauren R. Pugh, Peter J. Taylor and Katherine Berry, "The Role of Guilt in the Development of Post-traumatic Stress Disorder: A Systematic Review," Journal of Affective Disorders 182 (2015): 138-150; Deborah A. Lee, Peter Scragg, and Stuart Turner, "The Role of Shame and Guilt in Traumatic Events: A Clinical Model of Shame-based and Guilt-based PTSD," British Journal of Medical Psychology 74 (2001): 451-466.

18 Jeffrey Alexander, "Toward a Theory of Cultural Trauma," Cultural Trauma and Collective Identity (ed. Jeffrey Alexander et al.; Berkeley: University of California Press, 2004), 1.

19 On the following, see, with references, Dominik Markl, Gottes Volk im Deuteronomium (BZAR 18; Wiesbaden: Harrassowitz, 2012), 232-238. 
below, C). ${ }^{20}$ This proem forms a frame with the final verse, v. $43 .{ }^{21}$ The first major section of the text is introduced by the theme of God's righteousness (v. 4) as contrasted with the people's guilt (v. 5), which is unfolded in vv. 6-15, 16-18. This provokes God's anger (v. 19) which culminates in an accusatory divine speech that begins in v. 20 and reaches at least down to v. 27. There is a second divine speech in vv. 34f that is not explicitly introduced, but clearly distinguished from its context by the use of the first person singular, and the content which clarifies that the divine voice is speaking. The third divine speech is explicitly introduced in v. 37 and its end in v. 42 is indicated by the shift from the first person to the third person in the final verse, v. 43.

While exegetes widely agree on these observations, there is much disagreement as to where the first divine speech ends, be it after v. 27 (in which the first person singular is used for the last time) or later. ${ }^{22}$ Moreover, there is a dispute on whether vv. 28-30 are directed against Israel or against their enemies, which touches upon the question of the poem's turning point. While many interpreters see a decisive shift in v. $27,{ }^{23}$ when God announces that he will not completely annihilate his people out of fear for his fame among the nations, there are reasons to assume that this occurs only later in the poem, as will be shown in the following.

A first structural device that has been widely neglected in previous interpretations is that the Song employs questions at structurally significant points in vv. $6,20,34$ and $37::^{24}$

Verse 6 "Do you thus repay YHWH ...? Is not he your father ...?"

Verse 20 "I will hide my countenance from them; I will see: What is their end?" Verse 34 "Is not this laid up in store with me, sealed up in my treasuries?"

Verse 37 "Where are their gods, the rock in which they took refuge?"

20 Hubert Irsigler, "Das Proömium im Moselied Dtn 32: Struktur, Sprechakte und Redeintentionen von V. 1-3," in Lingua restituta orientalis. FS J. Aßfalg (ed. Regine Schulz and Manfred Görg; ÄAT 20; Wiesbaden: Harrassowitz, 1990), 161-174. The first-person singular of the prophetic voice occurs exclusively in vv. 1-3. On the formal coherence of vv.1-3, see ibid. 165 and Salvador Carrillo Alday, "Género literario del Cántico de Moisés (Dt. 32)," Estudios Bíblicos 26 (1967): 73.

21 Only in vv. 1 and 43 are vocatives employed in combination with imperatives by the voice of the poet. The theme of praise appears only in vv. 3 and 43.

22 Schmidtkunz, Das Moselied, 69, attributes vv. 28-29 to the divine voice.

23 Cf. Irsigler, "Das Proömium," 165; Jeffrey H. Tigay, Deuteronomy (Philadelphia: Jewish Publication Society, 1996), 309, describes Deut 32:26-42 as a major unit.

24 A fifth question in v. 30 is of lesser structural importance, since it is answered within the same verse. 
These questions are employed at strategic points in order to mark transitions and to introduce themes that are being unfolded in the following passages. The questions in v. 6 introduce the elaborate accusation against Israel in vv. 7-14, 15-18. The questions in vv. 20, 34, 37 are positioned at the beginning of each of the three divine discourses. God's first question "what is their (i.e. Israel's) end" is being treated in the following passages and even until the end of the Song. The enigmatic question of v. 34 alludes to God's future rescue of his people, which is unfolded in the following development of the text. The final rhetorical question about the idols in v. 37 is answered by the divine self-glorification in vv. 39-42.

A second noteworthy feature is that the first and the third divine speech (vv. 20-27, 37-42) contain a number of similarities:

- God "sees" (יראה / וירא), which prompts the speech

- Introduction of direct discourse by ואמר / ויאמר / ואר (איר /

$\begin{array}{ll}\text { vv. } 19 & 36 \\ \text { vv. } 20 & 37 \\ \text { vv. } 20 & 37 \\ \text { vv. } 21 & 39 \\ \text { vv. } 26 & 40 \\ \text { vv. } 27 & 40 \\ \text { vv. } 27 & 41 \mathrm{f} \\ \text { vv. } 23,25 & 41 \mathrm{f} \\ \text { vv. } 22 & 42\end{array}$

- Questions at the beginning (אי / מה)

- Programmatic statement with emphatic 1ps (איאה)

- Self-quotation introduced by אמרתי[1]

- Motifs: raised hand (יד)

- enemies (צויב and (יד)

- arrow (חקו) and sword (ארב) as divine weapons 42

The parallel rhetorical features and motifs highlight the contrasting messages of these divine discourses. Whereas God "sees" Israel's sin in v. 19, which causes his outraged speech (vv. 20-27), God also "sees" Israel's devastation in v. 36, prompting a speech that promises rescue (vv. 37-42). While the first introductory question is directed against Israel (v. 20), the second is against Israel's idols (v. 37). While God's self-quotation in the first speech threatens his people (v. 26), the other glorifies himself (v. 40). Whereas "arrow" and "sword" serve to damage Israel in the first speech (vv. 23, 25), they are God's weapons against Israel's enemies in his final discourse (vv. 41f).

A third observation concerns the questions in vv. 6 and 34. Both of them employ indexicals ("thus," זאת, v. 6 and "this," vוא, v. 34) that refer to themes that will be unfolded in the subsequent passages. ${ }^{25}$ These formulations cryptically foreshadow what is still to be uncovered in what follows. Israel is

25 On textual deixis in Hebrew, see Konrad Ehlich, "Deixis und Anapher," in Sprache und sprachliches Handeln 2. Prozeduren des sprachlichen Handelns (ed. idem; Berlin: de Gruyter, 2007), 5-24; idem, Verwendungen der Deixis beim sprachlichen Handeln: Linguistisch-philologische Untersuchungen zum hebräischen deiktischen System (Forum Linguisticum 24; Frankfurt a. M.: Peter Lang, 1979). 
seen to repay God "thus" only when their idolatry (vv. 15-18), despite God's nourishment and care (vv. 7-14), is unfolded. What is "laid up in store with" God and "sealed up" in his treasuries (v. 34), is unveiled by the poet's voice "indeed YHWH will vindicate his people, have compassion on his servants" (v. 36) - and in the following speech of God.

The three preceding observations, taken together, suggest that the negative tones in vv. 28-33 (that refer to Israel's stubbornness and their enemies' cruelty) are to be seen as prolonging the themes of accusation against and judgement of Israel. While God's decision not to destroy his people completely (v. 27) already hints at some possible future, the real turning point comes only with God's cryptic and unintroduced speech in v. 34. It is assumed that the Song as a whole is introduced in vv. 1-5 and it develops in two main movements of unequal length that describe firstly Israel's sin and God's punishment through Israel's enemies (vv. 6-33) and, secondly, God's compassion towards his people and his defeat of their enemies (vv. 34-43).

Vv. 1-5 Introduction: proem (1-3) and summary of leading themes (4-5)

First movement

Vv. 6-18 (6 introductory question)

divine care

Israel's idolatry (15-18)

Vv. 20-27 'I will hide My countenance,

let raise enemies over Israel!'

Vv. 28-33 God delivers Israel to enemies

\section{Second movement}

34-36 (34 introductory question)

divine compassion

37-42 'Where are their gods?

I will slay the enemy!'

43 God avenges Israel

Whereas the first movement (vv. 6-33) leaves little hope for Israel, the Song builds into the second movement that reverses the dynamics of the first, which is dramatically unfolded in the two contrasting divine discourses (vv. 20-27, 37-42). While God announces that he will hide his face at the beginning of the first (v. 20) and his absence brings devastation and suffering upon the people, the last divine discourse focuses on the absence, that is, non-existence of Israel's idols (v. 37, cf. v. 21). Now it is God's powerful presence (v. 39) that brings rescue and deliverance for his people. These structural observations highlight v. 34 as the most significant turning point within the Song. God's motivation not to annihilate his people first seems to consider nothing but his own fame (vv. 26f), but the reason for positive intervention and rescue is "laid up in store with me, sealed up in my treasuries" (v. 34) - a hidden reason, grounded in divine compassion (v. 36). While these first observations concentrated on the Song's textual structure and dynamics, I shall focus on rhetorical features in what follows. 


\section{BLAMING AND SHAMING}

Hubert Irsigler's analysis of the Song's proem (vv. 1-3) ${ }^{26}$ shows that these verses are a key to the interpretation of the Song as a whole. The opening invocation "Give ear, O heavens, and I will speak ..." (v. 1), if read in the context of Moses' announcement to take heaven and earth as witnesses (31:28), may be seen as alluding to the forensic function of the text, which is unfolded in 32:6-33 (see above, first movement). "May my teaching drop like the rain ..." (v. 2) highlights the Song's teaching dimension: it presents theological thought, characterizing YHWH especially in the metaphors of 'rock,' 'parent' and 'vulture. ${ }^{27}$ The metaphors of rain and dew suggest that this teaching is supposed to refresh and heal, which may be achieved through the consoling message of the Song's finale (vv. 34-43). "For the name YHWH I proclaim; Give glory to our God!" (v. 3) implies that the Psalm conveys a theological message that aims to evoke praise. This motif, in fact, recurs at the end of the Song: "Praise, O nations, his people!" While Israel here is the object of praise, divine deeds are the reason for it: "For he will avenge the blood of his children and take vengeance on his adversaries."

Whereas the aforementioned aspects of the Song's scope are explicitly stated at its beginning and are visible in the further development of the text, the Song also contains a significant feature that is not explicitly announced within the proem; ${ }^{28}$ it employs intense rhetoric of blaming and shaming. ${ }^{29}$ Israel is denounced as a "crooked, perverse generation" (v. 5), as a "foolish and senseless people" (v. 6), as "fat, bloated, and gorged" (v. 15); the divine voice calls them "a perverse generation, children in whom there is no faithfulness" (v. 20). Although God also calls Israel's enemies "a foolish nation" (v. 21), it seems most

26 Irsigler, "Das Proömium," 167-171. On the following, see the more detailed presentation in Markl, Gottes Volk, 239-242.

27 See the extensive analysis in Wüste, Fels, 107-258. On the 'rock' as a central metaphor of the theology of the Song of Moses, see also Georg Fischer, "Der Fels': Beobachtungen im Umfeld einer theologischen Metapher," in Sprachen - Bilder Klänge: Dimensionen der Theologie im Alten Testament und in seinem Umfeld. FS Rüdiger Bartelmus (ed. Christiane Karrer-Grube et al.; AOAT 359, Münster: UgaritVerlag, 2009), 23-33, esp. 29.

28 The complex diversity of the Song's pragmatic scopes is mirrored in the diverse attempts to identify the Song's genre. See the surveys in Sanders, Provenance, 84-96, and Salvador Carrillo Alday, El Cantico de Moises (Dt 32) (Madrid: Consejo Superior de Investigaciones Científicas, 1970), 127-133.

29 The rhetoric of blaming and shaming is related to the forensic dimension of the Song that is highlighted in its characterization as a "witness" against Israel in the narrative context $(31: 19,21)$. Several authors tried to relate parts of the Song itself to the 'rîb-pattern'; cf. Sanders, Provenance, 86-91; Matthew Thiessen, "The Form and Function of the Song of Moses (Deuteronomy 32:1-43)," JBL 123 (2004): 401-424. 
likely that "a nation void of sense ..." (vv. 28f) refers again to Israel. ${ }^{30}$ Even in the Song's final section, a rhetoric of shame is employed. God's ironic question "Where are their gods, the rock in which they took refuge, who ate the fat of their sacrifices, and drank the wine of their libations?" ridicules Israel's idolatry. The only word that is directly addressed to Israel within God's speeches is "see!" (ראו, v. 39), drawing the people's attention to YHWH's unique rescuing power: "I, I am He; there is no god besides me! I kill and I make live; I wound, and I heal." The people are not accorded any merit for their survival and rescue from their enemies. The final praise of the nations (v. 43) is to address a people shamed and humbled by their own God throughout the poem. ${ }^{31}$ The experience of historical disaster as a result of guilt means humiliation for the audience; honour can only be re-gained through their unique God.

While the rhetoric of blaming and shaming is a significant feature of the Song, the question remains as to why an audience that has suffered terrible defeat is - to make things worse - blamed and shamed by the most authoritative voices of the prophet and God. Before coming back to this question, I shall discuss the Song's role within its context in the book of Deuteronomy, which will bring its profile into a sharper focus.

\section{THE SONG IN THE CONTEXT OF DEUTERONOMY}

The language, style and content of the Song of Moses show an ambiguous relationship with their literary context, the book of Deuteronomy. ${ }^{32}$ The Song and Moses' blessing (Deut 33) are alien elements within Deuteronomy as the only two poetic texts within a book that is generally marked by a stylistically specific type of prose rhetoric within a narrative framework. Moreover, much of the vocabulary employed within these poems is exceptionally rare and only a few formulations connect the Song with the rest of the book beyond its narrative introduction (31:16-30) and the blessing (Deut 33). ${ }^{33}$ There are good reasons,

\footnotetext{
30 See Schmidtkunz, Das Moselied, 70f. Verse 30 clearly refers to Israel: "How could one have routed a thousand, and two put a myriad to flight, unless their Rock had sold them, YHWH had given them up?"

31 Within Deuteronomy, the Song can be compared to other passages that involve rhetoric of praise and blame that aims at forming Israel's moral identity such as Deut 4:6-8, 33f; 7:6f; 9:6, 13; 14:2; 26:19; 33:29. Cf. Markl, Gottes Volk, 85-87; idem, "Moses' Praise and Blame-Israel's Honour and Shame: Rhetorical Devices in the Ethical Foundations of Deuteronomy," Verbum et Ecclesia 34 (2013) Art. \#861, 4 pages, http://dx.doi.org/10.4102/ve.v34i2.861.

32 See, more details in Markl, Gottes Volk, 242-252.

33 An important example of a theme that combines the Song of Moses with the rest of the book is the worship of "gods" that Israel had "not known" (אלהים + לא + ידע): Deut 11:28; 13:3, 7, 14; 28:64; 29:25; 32:17 (beyond Deut just Jer 7:9; 19:4; 44:3); cf. Sanders, Provenance, 395.
} 
therefore, to argue that the Song originated independently from the book of Deuteronomy, and that the narrative framework of 31:16-30 and 32:44 was created to integrate the Song at a late stage of the Pentateuch's redaction. ${ }^{34}$

At the same time, the historiographical pattern of Israel's guilt, punishment and restoration connects the Song thematically with Deut 4:25-31 and 29:17-30:10 (within the context of the Moab covenant discourse, Deut 29$30)$. These texts are connected with the Song via the motif of invoking heaven and earth as witnesses $(4: 26 ; 30: 19 ;$ cf. 31:28; 32:1). In Deut 4:23-31, this motif emphasises the destructive consequences of idolatry, and in 30:15-20, it places urgency on the decision for YHWH and his Torah. In both passages, the motif is related to the admonition not to make idols (4:23) and not to worship other gods (30:17). In the Song and its narrative embedding, the function of the cosmic witnesses is different. As Israel's future sin is a matter of God's certain knowledge (31:21), heaven and earth now stand as witnesses against the people whose actual sin is presupposed and portrayed in retrospect. Israel's conversion, a decisive prerequisite for restoration in Deut 4:30 35 and 30:1-10, is never mentioned within the Song.

Two further contrasts between Deut 29-30 and the Song highlight their different rhetorical aims.

29:28 "The secret things belong to YHWH our God"

30:19 "I have put before you life and death ... Choose life!"
32:34 "Is not this laid up in store with me, sealed up in my treasuries?" 36

32:39 "I deal death and give life; ... None can deliver from My hand!"

34 On the history of research, see Otto, Deuteronomium, 2163; Otto himself considers the Song and its narrative framework contemporary (ibid., 2164). Leuchter, in contrast, argues for an origin of the Song in the early monarchy and its integration into the book of Deuteronomy in the Josianic period; Mark Leuchter, "Why is the Song of Moses in the Book of Deuteronomy?" VT 57 (2007): 295-317. The narrative analysis of the frame shows how the writing of the Song (Deut 31:24-26) is portrayed as a "supplement" to Moses' Torah book; cf. Jean-Pierre Sonnet, The Book within the Book: Writing in Deuteronomy (BiInS 14; Leiden: Brill, 1997), 156-167. The differences between MT and LXX in the narrative framework are additional evidence for diverging redactional processes. See Karin Finsterbusch, "Integrating the Song of Moses into Deuteronomy and Reshaping the Narrative: Different Solutions in MT Deut 31:1-32:47 and (the Hebrew Vorlage of) LXX Deut 31:1-32:47," in The Formation of the Pentateuch: Bridging the Academic Cultures of Europe, Israel, and North America (ed. Jan C. Gertz et al.; FAT 111; Tübingen: Mohr Siebeck, 2016), 631-650.

35 Restoration is alluded to in the motif of divine mercy in Deut 4:31.

36 On the motif of the divine 'treasury' see Schmidtkunz, Das Moselied, 224-227, and Christopher T. Begg, "Access to Heavenly Treasuries: The Traditionsgeschichte of a Motif," BN 44 (1988): 15-20. 
The two enigmatic verses 29:28 and 32:34 do not have any specific vocabulary in common, but they are the only passages in Deuteronomy that share the idea of something being hidden in the divine sphere. Moreover, both verses stand at a turning point between catastrophic destruction $(29: 19-27 ; 32: 19-33)$ and restoration $(30: 1-10 ; 32: 35-43)$. The interpretation of what is hidden in the divine sphere is highly disputed, but several authors have argued that the "hidden things" refer to (divine action and the people's fate in) the future, which is inaccessible to human knowledge. ${ }^{37}$ Whereas the speaking we-group in Deut 29:28 leaves any hidden matter to God alone and emphasises the necessity of fulfilling the Torah "for us and for our children forever," in 32:34 God himself speaks and announces what is hidden in his sphere - the deliverance of his people. The second thematic connection concerns the source of Israel's life. While Moses incites Israel to choose God and the Torah, on which life or death depend, at the culmination of his Moab covenant discourse (30:19), the divine voice declares in the final climax of the Song that life and death are determined by God alone (32:39).

These thematic connections show contrastive theological emphases and rhetorical aims in the redacted form of the book. While Moses' exhortation to obey the Torah (Deut 29-30) also implies conversion as a prerequisite for the change of fate (Deut 4:29; 30:1f), the Song attributes the people's rescue solely to God's merciful action (32:34-43). The Moab covenant discourse emphasizes human effort to fulfil the Torah, rejects concern for God's hidden plans (29:28) and equates human obedience to the Torah with the choice between life and death (30:19). The Song's additional revelation presents God's hidden plans as the only source of rescue and himself as the only sovereign over life and death (32:39). While these different accents are likely to originate in different theological interests of different authors and times, the redacted form of the Pentateuch integrates these tensions and contrasting theological accentuations. Moses repeats his exhortative message after the Song (32:46-47), reviving the idea of Deut 30 that the "word" is "your life" (cf. 30:14, 19f). Within this framework, the Song urges acknowledgement of YHWH as the unique source of salvation, which may consequently lead to conversion and Torah-obedience. ${ }^{38}$

37 Cf. Otto, Deuteronomium, 2065; Alan Lenzi, Secrecy and the Gods: Secret Knowledge in Ancient Mesopotamia and Biblical Israel (SAA.S 19, Helsinki: NeoAssyrian Text Corpus Project, 2008), 328-339. On the early interpretation of this verse in Qumran, see Shani Tzoref, "The 'Hidden' and the 'Revealed': Esotericism, Election, and Culpability in Qumran and Related Literature," in The Dead Sea Scrolls at 60: Scholarly Contribution of New York University Faculty and Alumni (ed. Lawrence H. Schiffman and Shani Tzoref; STDJ 89; Leiden: Brill, 2010), 299-324.

38 According to Deut 30, Torah-obedience will depend on the circumcision of the heart (30:6). Cf. Ernst Ehrenreich, Wähle das Leben! Deuteronomium 30 als hermeneutischer Schlüssel zur Tora (BZAR 14; Wiesbaden: Harrassowitz, 2011), 197-200, 274. 
The Song of Moses thus brings about a major shift in how Israel's 'future' fate is depicted in Deuteronomy. Within the preceding discourses by Moses, Israel's defeat because of future sin is envisioned in conditional warnings (introduced by 9 , "lest," both in 4:23-31 and 29:17-27) or as a conditional curse (Deut 28:15-68). ${ }^{39}$ The Song, in contrast, refers to Israel's history of defeat in a retrospective mode. Israel's future sin and disaster are unavoidable, referred to in a prophetic accusation of sin that actually (would have) happened. The Song's contextualisation within Deuteronomy thus puts its stark message into even sharper profile.

\section{E EXTERNALISED SELF-BLAME AND CULTURAL TRAUMA}

The overall structure and dynamics, the rhetorical force and the literary contextualisation of the Song of Moses within Deuteronomy pose the question as to why it conveys a message of blame and shame to a defeated people at a structurally elevated position towards the end of the Pentateuch. ${ }^{40}$ In contrast to other texts of the Hebrew Bible that lament suffering (in particular, Lamentations), challenge God to intervene (e.g. Pss 44; 74; Isa 63:7-64:11) or convey a message of consolation (e.g. Isa 40), the Song of Moses employs elaborate poetic techniques to convey a harsh message of blame and shame against those who experienced suffering. The responsibility for defeat and suffering is attributed solely to Israel, the merit of the people's rescue solely to God. From a theological point of view, the Song advocates for theodicy. Instead of accusing or, at least, challenging YHWH (e.g. Lam 5:21f; Ps 44), God is given the role of the prosecutor, while the people have no voice and neither do they play any active role in their survival within the Song. From a human psychological and sociological - perspective, we should ask what could have motivated the composition of such a harsh text. Trauma theory may help to shed some light on this question.

The interpretation of destruction and defeat as a consequence of divine wrath caused by human guilt is found in many ancient Near Eastern texts and is pervasive in the Hebrew Bible, as it occurs in Deuteronomistic historiography,

39 On these and other relevant passages, see the section on "Disobedience and the Loss of the Land" in Dominik Markl, "The Efficacy of Moses's Prophecies and the Scope of Deuteronomistic Historiography," in Collective Memory and Collective Identity: Case Studies in Deuteronomy and the Deuteronomistic History (ed. Johannes Unsok Ro and Diana Edelman; BZAW 534; Berlin: De Gruyter, 2021), 128-132.

40 The Song's provocative impact may be seen in its subversive reception in the book of Job, as argued by Edward L. Greenstein, "Parody as a Challenge to Tradition: The Use of Deuteronomy 32 in the Book of Job," in Reading Job Intertextually (ed. Katherine Dell and Will Kynes; LHB/OTS 574; New York: Bloomsbury 2013), 66-78. 
prophetic literature, Lamentations and Psalms. ${ }^{41}$ From a psychological point of view, the motif of divine wrath and prosecution of guilt can be viewed as an externalised act of self-blame. ${ }^{42}$ With all due caution concerning the significant cultural differences between contemporary concepts of trauma and the cultural meaning of suffering in ancient Israel and Judah, contemporary psychological recognition of guilt and shame as post-traumatic feelings could lend probability to the hypothesis that the rhetoric of blaming and shaming in the Song of Moses externalises and transforms post-traumatic feelings of guilt and shame.

The Song's literary refinement indicates that it is not a spontaneous individual reaction to trauma. On the contrary, it presupposes intense intellectual reflection and some historical distance from the events on which it reflects, possibly mediated across generations. ${ }^{43}$ The defeat that looms large behind the text corresponds quite well with a description of cultural trauma - the perception of "a horrendous event that leaves indelible marks," defining the community's "future identity in fundamental and irrevocable ways" (as noted earlier). The narrative frame conceives the Song as a central document for the audience's collective identity, since it requires all Israelites to learn the Song by heart so that it acts as a witness in their own mouth (Deut 31:19) - and the mouth of their descendants (31:21), that is, Deuteronomy's addressees. ${ }^{44}$ While reflection on the psychological background of ancient texts is necessarily hypothetical and speculative, trauma theory may help explain the rhetoric of blaming and shaming employed in the Song of Moses at the culmination of the Pentateuch. The Song may be understood as an intellectually worked through externalisation of selfblame and shame, an elaborate expression of cultural trauma.

41 Reinhard G. Kratz and Hermann Spieckermann, eds., Divine Wrath and Divine Mercy in the World of Antiquity (FAT II 33; Tübingen: Mohr Siebeck, 2008); JeanMarie Durand, Lionel Marti and Thomas Römer, eds., Colères et repentirs divins: Actes du colloque organisé par le Collège de France, Paris, les 24 et 25 avril 2013 (OBO 278; Göttingen: Vandenhoeck \& Ruprecht, 2015); Ulrich Berges, "Der Zorn Gottes in der Prophetie und Poesie Israels auf dem Hintergrund altorientalischer Vorstellungen," Biblica 85 (2004): 305-330.

42 On shame and self-blame as typical consequences of trauma see above, section A.

43 On the transgenerational mediation of trauma and the construction of cultural trauma in discourse, see the references in Markl, "Babylonian Exile," 7-9.

44 On the construction of the Song as a "cloud of witnesses," see Markl, Gottes Volk, 246f. For reflection on memory and identity in relation to the Song of Moses, see Nilsen, The Origins, 187-239, esp. 233. Without employing theory about social memory, Schmidtkunz, Das Moselied, 377, similarly arrives at the conclusion that, "Angesichts ihrer politischen Unselbständigkeit sollte es [i.e., Deut 32] die Hörerschaft an ihre existenzielle Verwiesenheit auf JHWH erinnern, hinsichtlich der Bandbreite an überlieferten Traditionen wiederum an ihre kollektive Identität als Gottesvolk." 


\section{F BIBLIOGRAPHY}

Becker, Eve-Marie et al., eds. Trauma and Traumatization in Individual and Collective Dimensions: Insights from Biblical Studies and Beyond. Studien zum Alten und Neuen Testament 2. Göttingen: Vandenhoeck \& Ruprecht, 2014.

Begg, Christopher T. "Access to Heavenly Treasuries: The Traditionsgeschichte of a Motif." Biblische Notizen 44 (1988): 15-20.

Berges, Ulrich. "Der Zorn Gottes in der Prophetie und Poesie Israels auf dem Hintergrund altorientalischer Vorstellungen.” Biblica 85 (2004): 305-330.

Boase, Elizabeth and Christopher G. Frechette, eds. Bible through the Lens of Trauma. Semeia Studies 86. Atlanta, GA: Society of Biblical Literature, 2016.

Braulik, Georg. "Hat Gott die Religionen der Völker gestiftet? Deuteronomium 4,19 im Kontext von Kultbilderverbot und Monotheismus." Pages 142-251 in Tora und Fest: Aufsätze zum Deuteronomium und zur Liturgie. Edited by Georg Braulik. Stuttgarter Biblische Aufsatzbände 69. Stuttgart: Katholisches Bibelwerk, 2019.

Carr, David M. Holy Resilience: The Bible's Traumatic Origins. New Haven: Yale University Press, 2014.

Carrillo Alday, Salvador. "Género literario del Cántico de Moisés (Dt. 32)." Estudios Bíblicos 26 (1967): 69-75.

Carrillo Alday, Salvador. El Cantico de Moises (Dt 32). Madrid: Consejo Superior de Investigaciones Científicas, 1970.

Durand, Jean-Marie, Lionel Marti and Thomas Römer, eds. Colères et repentirs divins: Actes du colloque organisé par le Collège de France, Paris, les 24 et 25 avril 2013. Orbis Biblicus et Orientalis 278. Göttingen: Vandenhoeck \& Ruprecht, 2015.

Ehlich, Konrad. "Deixis und Anapher." Pages 5-24 in Sprache und sprachliches Handeln 2: Prozeduren des sprachlichen Handelns. Berlin: de Gruyter, 2007.

Ehlich, Konrad. Verwendungen der Deixis beim sprachlichen Handeln: Linguistischphilologische Untersuchungen zum hebräischen deiktischen System. Forum Linguisticum 24. Frankfurt a. M.: Peter Lang, 1979.

Ehrenreich, Ernst. Wähle das Leben! Deuteronomium 30 als hermeneutischer Schlüssel zur Tora. Beihefte zur Zeitschrift für Altorientalische und Biblische Rechtsgeschichte 14. Wiesbaden: Harrassowitz, 2011.

Finsterbusch, Karin. "Integrating the Song of Moses into Deuteronomy and Reshaping the Narrative: Different Solutions in MT Deut 31:1-32:47 and (the Hebrew Vorlage of) LXX Deut 31:1-32:47." Pages 631-650 in The Formation of the Pentateuch: Bridging the Academic Cultures of Europe, Israel, and North America. Edited by Jan C. Gertz et al. Forschungen zum Alten Testament 111. Tübingen: Mohr Siebeck, 2016.

Fischer, Georg. “'Der Fels': Beobachtungen im Umfeld einer theologischen Metapher." Pages 23-33 in Sprachen-Bilder-Klänge: Dimensionen der Theologie im Alten Testament und in seinem Umfeld. FS Rüdiger Bartelmus. Edited by Christiane Karrer-Grube et al. Alter Orient und Altes Testament 359. Münster: UgaritVerlag, 2009.

Garber, David G. "Trauma Theory and Biblical Studies." Currents in Biblical Research 14 (2015): 24-44. 
Greenstein, Edward L. "Parody as a Challenge to Tradition: The Use of Deuteronomy 32 in the Book of Job." Pages 66-78 in Reading Job Intertextually. Edited by Katherine Dell and Will Kynes. Old Testament Studies 574. New York: Bloomsbury 2013.

Irsigler, Hubert. "Das Proömium im Moselied Dtn 32: Struktur, Sprechakte und Redeintentionen von V. 1-3." Pages 161-174 in Lingua restituta orientalis. FS J. Aßfalg. Edited by Regine Schulz and Manfred Görg. Ägypten und Altes Testament 20. Wiesbaden: Harrassowitz, 1990.

Kratz, Reinhard G. and Hermann Spieckermann, eds. Divine Wrath and Divine Mercy in the World of Antiquity. Forschungen zum Alten Testament II 33. Tübingen: Mohr Siebeck, 2008.

Lee, Deborah A., Peter Scragg and Stuart Turner. "The Role of Shame and Guilt in Traumatic Events: A Clinical Model of Shame-based and Guilt-based PTSD." British Journal of Medical Psychology 74 (2001): 451-466.

Lenzi, Alan. Secrecy and the Gods: Secret Knowledge in Ancient Mesopotamia and Biblical Israel. SAA.S 19. Helsinki: Neo-Assyrian Text Corpus Project, 2008.

Leuchter, Mark. "Why Is the Song of Moses in the Book of Deuteronomy?" Vetus Testamentum 57 (2007): 295-317.

Markl, Dominik. Gottes Volk im Deuteronomium. Beihefte zur Zeitschrift für Altorientalische und Biblische Rechtsgeschichte 18. Wiesbaden: Harrassowitz, 2012.

Markl, Dominik. "Moses' Praise and Blame-Israel's Honour and Shame: Rhetorical Devices in the Ethical Foundations of Deuteronomy." Verbum et Ecclesia 34 (2013) Art. \#861, 4 pages. http://dx.doi.org/10.4102/ve.v34i2.861.

Markl, Dominik. "The Babylonian Exile as the Birth Trauma of Monotheism." Biblica 101 (2020): 1-25.

Markl, Dominik. "The Efficacy of Moses's Prophecies and the Scope of Deuteronomistic Historiography." Pages 121-147 in Collective Memory and Collective Identity: Case Studies in Deuteronomy and the Deuteronomistic History. Edited by Johannes Unsok Ro and Diana Edelman. Beihefte zur Zeitschrift für die Alttestamentliche Wissenschaft 534. Berlin: De Gruyter, 2021. Markl, Dominik. "Trauma/Traumatheorie." No pages in WiBiLex. Cited 14 December 2020. Online: https://www.bibelwissenschaft.de/stichwort/41144/.

Morrow, William. "Deuteronomy 7 in Postcolonial Perspective: Cultural Fragmentation and Renewal." Pages 275-293 in Interpreting Exile: Displacement and Deportation in Biblical and Modern Contexts. Edited by Brad E. Kelle, Frank Ritchel Ames and Jacob L. Wright. Society of Biblical Literature Ancient Israel and Its Literature 10. Atlanta: Society of Biblical Literature, 2011. Nigosian, Solomon A. "Historical Allusions for Dating Deut 32." Biblische Notizen 119/120 (2003): 30-34.

Nilsen, Tina Dykesteen. The Origins of Deuteronomy 32: Intertextuality, Memory, Identity. New York: Peter Lang, 2018.

Otto, Eckart. "Moses Abschiedslied in Deuteronomium 32." Pages 641-678 in Die Tora: Studien zum Pentateuch. Gesammelte Aufsätze. Beihefte zur Zeitschrift für Altorientalische und Biblische Rechtsgeschichte 9. Wiesbaden: Harrasswitz, 2009.

Otto, Eckart. Deuteronomium 32,16-34,12. Herders Theologischer Kommentar zum Alten Testament. Freiburg: Herder, 2017. 
Pugh, Lauren R., Peter J. Taylor and Katherine Berry. "The Role of Guilt in the Development of Post-traumatic Stress Disorder: A Systematic Review." Journal of Affective Disorders 182 (2015): 138-150.

Sanders, Paul. The Provenance of Deuteronomy 32. Old Testament Studies 37. Leiden: Brill, 1996.

Schenker, Adrian. "Das Paradox des israelitischen Monotheismus in Dtn 4,15-20. Israels Gott stiftet Religion und Kultbilder der Völker." Pages 511-528 in Bilder als Quellen. Images as Sources: Studies on Ancient Near Eastern Artefacts and the Bible Inspired by the Work of Othmar Keel. Orbis Biblicus et Orientalis Sonderband. Fribourg: Academic Press/Göttingen: Vandenhoeck \& Ruprecht, 2007.

Schmidtkunz, Petra. Das Moselied des Deuteronomiums: Untersuchungen zu Text und Theologie von Dtn 32,1-43. Forschungen zum Alten Testament 2. Reihe 124. Tübingen: Mohr Siebeck, 2020.

Sonnet, Jean-Pierre. The Book within the Book: Writing in Deuteronomy. Biblical Interpretation Series 14. Leiden: Brill, 1997.

Sonnet, Jean-Pierre. "Voix divines dans le cantique de Moïse (Deutéronome 32)." Pages 153-173 in La contribution du discours à la caractérisation des personnages bibliques: Neuvième colloque international du RRENAB, Louvainla-Neuve, 31 mai-2 juin 2018. Edited by André Wénin. Bibliotheca Ephemeridum Theologicarum Lovaniensium 311. Leuven: Peeters, 2020.

Startup, Mike, Lebogang Makgekgenene, and Rosemary Webster. "The Role of Selfblame for Trauma as Assessed by the Posttraumatic Cognitions Inventory (PTCI): A Self-protective Cognition?" Behaviour Research and Therapy 45 (2007): 395403.

Thiessen, Matthew. "The Form and Function of the Song of Moses (Deuteronomy 32:1-43)." Journal of Biblical Literature 123 (2004): 401-424.

Tigay, Jeffrey H. Deuteronomy. Philadelphia: Jewish Publication Society, 1996.

Tzoref, Shani. "The 'Hidden' and the 'Revealed': Esotericism, Election, and Culpability in Qumran and Related Literature." Pages 299-324 in The Dead Sea Scrolls at 60: Scholarly Contribution of New York University Faculty and Alumni. Edited by Lawrence H. Schiffman and Shani Tzoref. Studies on the Texts of the Desert of Judah 89. Leiden: Brill, 2010.

Volkwein, Bruno. Textkritische Untersuchungen zu Dtn 32,1-43. Ph.D. diss., Pontifical Biblical Institute, Rome, 1973.

Wüste, Christiane. Fels-Geier-Eltern: Untersuchungen zum Gottesbild des Moseliedes (Dtn 32). Bonner Biblische Beiträge 182. Göttingen: V\&R Unipress, 2018.

Dominik Markl is Professore straordinario of Hebrew Bible/Old Testament at the Pontifical Biblical Institute in Rome and Research Associate at the Department of Old Testament and Hebrew Scriptures, Faculty of Theology and Religion, University of Pretoria, South Africa. E-mail: markl@ biblico.it ORCID: https://orcid.org/0000-0002$\underline{5202-048 X}$ 